\title{
The Analysis Of The Rural Credit Market In Ghana
}

\author{
George Owusu-Antwi, Nova Southeastern University, USA
} James Antwi, Ghana Institute of Management, Ghana

\begin{abstract}
The formal banking sector does not satisfy the growing demand for credit, and many borrowers turn to informal loan sources to meet their production and consumption needs. The problem of the rural credit, which includes supplying credit for a rural community for economic growth, is reemerging on the development agenda as a pressing issue. The rural economy is financially very fragile. Lack of credit is a significant and sometimes binding constraint, limiting investment in productivity-enhancing technology and inputs. Rural credit plays a critical role in household strategies to reduce vulnerability. In spite of the contribution that credit entails to the rural development, it has been one of the crucial factors that have not been given proper attention. The purpose of this paper is to identify problems that have hindered the effectiveness of the rural credit market in Ghana. The paper is premised on the theoretical understanding of rural credit markets and applies the framework to investigate the aspect of the rural credit market in Ghana. Improving the rural credit system will help to raise household incomes and reduce poverty and will contribute to the eradication of extreme poverty. The paper identifies high cost, interest rate, lack of collateral, lack of innovation and high delinquency rates as the main factors that have hindered the effectiveness of the rural credit market in Ghana. This paper will interest policymakers to place more emphasis on savings mobilization and to revisit interest rate policy, while providing cheap and adequate credit to small and poor farmers.
\end{abstract}

Keywords: Rural Credit, Informal and Formal Credit, Institutional, Markets

\section{INTRODUCTION}

$\mathscr{J}$ he formal banking sector does not satisfy the growing demand for credit, and many borrowers turn to informal loan sources (relatives, private moneylenders, etc.) to meet their production and consumption needs. It has been estimated that only 5 percent of the farmers in Africa and about 15 percent in Asia and Latin America have had access to formal credit; and on an average, across developing countries, 5 percent of the borrowers have received 80 percent of the credit (Bali Swain, 2001). The problem of rural credit, which includes supplying credit for rural communities for economic growth, is reemerging on the development agenda as a pressing issue. Lack of credit in Ghana has been identified as one of the major constraints limiting agricultural growth. Especially small farmers, whose contribution to agriculture production is crucial, are not benefiting from existing credit sources. Credit facilities, upon which the development of their farms, often depends are very limited. In this respect, Ghana is no exception. The credit capacity of most of the small farmers in Ghana is limited. There is growing evidence that financial needs of the rural communities - especially communities with dependency on agriculture - remain unmet and developing an efficient, sustainable and accessible rural credit system continues to present a significant challenge.

In Ghana, institutional credit can play an important role in improving agricultural production. Beneficiaries of institutional credit are mainly large-scale farmers who can provide collateral in the form of land and houses. Unfortunately, such farmers constitute only 20 percent of the farming population. Small-scale farmers face the problem in adopting improved inputs and modern technologies because of limited credit facilities. The result has undermined their ability to increase output and income. 
The sources of credit for small-scale farmers are mainly noninstitutional; that is, by local moneylenders. Noninstitutional credit is costly and is incapable of expansion. The credit institutions (mainly banks) that control almost all the consolidated financial assets in the country constitute the major source of credit to agriculture. Evidence has shown, however, the reluctance on the part of banks to lend to the agricultural sector. For the most part, the banks prefer to select customers who have a regular nonfarm income than the small-scale farmer whose income or produce depends on the vagaries of the weather. More often than not, the loans that are offered by the banks to the rural sectors do not go to the typical small farmers, but to employers of farms as second sources of income. The main reason often given by banks for not lending to agriculture is the high default risk, uncertainty and risk inherent in agricultural production and marketing. Among other reasons usually cited are the high cost of lending to small farmers, lack of collateral, the low rate of interest on agricultural loans, and the long-term nature of agricultural loans which is not compatible with bank lending, particularly in situations of high risk. For the past two decades, the performance of many of the credit institutions that specialized on agricultural lending in Ghana has deteriorated. The result has affected the enthusiasm that policymakers had for specialized agricultural lenders (ISSER, 1994).

According to Yaron et.al. (1997), most developing countries abandoned subsidized rural or agricultural credit programs in the 1980s, partly because the programs had met with little success globally and partly due to the influence of the financial system's approach adopted as part of the liberalization of the financial sector. The need for credit support development of agriculture-based livelihoods has been stressed, particularly as a justification for the state and donor-supported subsidized credit programs of the 1950s-1970s (World Bank, 2004). However, the rural economy is financially very fragile. Lack of credit is a significant and sometimes binding constraint, limiting investment in productivity-enhancing technology and input. Rural credit plays a critical role in household strategies to reduce vulnerability. It assists the poor to smooth consumption and to build up assets greater than the value of the liability (Gonzalez-Vega, 2003). The demand for rural credit has been growing since the 1986 reforms brought new economic opportunities to farmers, who make up 80 percent of the total population. The consequence is the existence of an informal credit market that provides loans to rural households for various purposes, at interest rates normally higher than that charged by the formal sector. In spite of the contribution that credit entails to the rural development, it has been one of the crucial factors that have not been given proper attention. The purpose of this paper is to identify problems that have hindered the effectiveness of the rural credit market in Ghana. The paper specifically examines the issues that need to be considered and or addressed in pursuing policies to make rural credit more readily available and beneficial to the poor in Ghana. The paper is premised on the theoretical understanding of rural credit markets and applies the framework to investigate the aspect of the rural credit market in Ghana. Improving the rural credit system will help to raise household incomes and reduce poverty.

\section{THEORY OF RURAL CREDIT MARKET}

Credit markets are characterized by certain problems, particularly problems related to risk and information, which distinguish them from ordinary markets, for example, goods. The credit market provides opportunities for making intertemporal choices of consumption (Varian, 1990). Hoff and Stiglitz (1996) propose three competing theories of the rural credit markets in developing countries. The first theory hypothesizes that village moneylenders in the informal market are monopolists, charging as high an interest rate as they can to maximize profits. Although a certain degree of monopoly power is present in the sense that there are often high transaction costs of switching lenders, this characterization is not complete if we are to gain a thorough understanding of this highly complicated market. Further, the monopoly theory does not explain the coexistence of the formal and informal credit market despite the fact that formal interest rates are substantially below those charged in the informal sector.

The second theory distinguishes that the rural credit market to be almost perfectly competitive with market clearing equilibrium, where high interest rates indicate high risk of borrowers. Again, this theory is not fully supported empirically, given the widespread observation of credit rationing in the rural market. Credit rationing refers to the phenomenon in which, among loan applicants who appear to be identical, some receive a loan and others do not and the rejected applicants would not receive a loan even if they paid a higher interest rate (Stiglitz and Weiss, 1981). 
The third approach is likely to be the most promising in facilitating our understanding of the rural credit market. This imperfect information school assumes that the informal credit market is characterized by uncertainty, high transaction costs, and information asymmetry, which typically leads to moral hazard and adverse selection. In order to overcome the informational asymmetry, lenders use indirect (passive) or direct (active) screening mechanisms to reveal the quality (risk level) of borrowers. In the indirect screening case, the interest rate can take on the dual function as both price and an indirect screening device. Indirect screening, therefore, often leads to credit rationing a combination of price and quantity of credit that is below the market clearing level. This is directly related to Stigliz and Weiss's (1981) price-quality theorem, which says that when the expected quality of a commodity is a function of its price, as in the case of credit, equilibrium may be represented by quantity rationing. Credit suppliers can also use direct screening mechanisms such as geography, kinship, and interlinkages with other markets to solve the problems of information, incentives and enforcement. In this case, the market will be monopolistically competitive. Hoff-Stiglitz's theory does provide an explanation of the phenomenon under study. However, empirical support for that thesis is rather thin. Evidence from most other studies puts a question mark on the very basic attributes of the model, namely, pervasiveness of incomplete and asymmetric information and arbitrage between institutional and private credit.

\section{RURAL CREDIT MARKETS}

In rural credit markets, problems which are present in all credit markets are aggravated, due to the special environment. Below, a framework will be presented for dividing these problems into three groups, problems related to screening, incentives, and enforcement of credit.

\section{The Screening Problem}

The presence of risk and the related problem of imperfect information are common to all credit markets. With regard to financial markets, Stiglitz (1994) goes as far as to say that their "essential role is to obtain and process information." The screening problem entails assessing the risk of the borrower, which may vary considerably. With information asymmetry comes the risk of adverse selection. The information is said to be asymmetric in the following case: "when two parties enter a contract, one may have information that would-if it were known to the other party - change the nature of the contract (Long, 1994). Generally, adverse selection arises when the agent conceals information and can use contract agreements to an extent not foreseen by the principal (Besley, 1994). In the case of credit markets, the lender is the principal and the borrower the agent. An interest rate set high to cover the risk of default, may attract only borrowers with very risky projects, since only projects with high variance can generate outcomes that make the loan profitable for the borrower. However, a negative outcome is particularly disadvantageous for the credit. A credit that raises interest rates to compensate for risky projects makes the composition of the loan portfolio even more risky, which is a consequence of adverse selection.

\section{The Incentive Problem}

The problem of borrowers' incentives is often referred to as moral hazard. Moral hazard is another phenomenon arising from incomplete information. It means that after the contract is closed between the lender and the borrower, the borrower may have incentives to change his course of action in ways negative for the lender (Milgrom and Roberts, 1992). After receiving a loan for a specific project or purpose, the borrower might want to change to a more risky project. Another temptation facing the borrower is to invest little effort in making his project a successful one since it is not mainly his own money which is at stake. Lenders usually try to restrict this behavior, either through providing incentives for project fulfillment or through closer monitoring. If the borrower does alter his plans, little time will lapse before it comes to the lender's knowledge.

\section{The Enforcement Problem}

When payment is due, the problem of enforcement arises. Besley (1994) defines a pure enforcement problem as "a situation in which the borrower is able but unwilling to repay." He argues that the problem of enforcement is the central difference between rural credit markets and other credit markets, since normal institutions for enforcement credit, as courts and police, are often underdeveloped or nonexistent, in the rural areas of developing countries. 
Different mechanisms affect the problems described above, and are used to alleviate them. If lenders could spend infinite resources on accessing information about the borrower and enforcing the contract, problems of screening, monitoring and enforcing contracts would not exist. Many institutions and market practices can be seen as responses to the problems of limits to commitment and asymmetric information. Commitment is limited whenever it is prohibitively costly to write and enforce detailed contracts. Information is asymmetric whenever it is too costly for one party to find out about the characteristics or actions of another party market arrangement that limit the problems without being too expensive are sought after. At the core of overcoming the difficulties described above lies the concept of transaction costs. Transaction costs not only make credit more expensive; in many cases they also prevent different transactions from taking place. For instance, the costs for handling very small loans easily become so high that the interest rate required to cover these costs causes the markets to disappear (Stiglitz, 1994).

Standardized loan application procedures, with computerized check-ups on the potential of the borrower's financial situation and demands of collateral in the form of real estate, are common features of credit markets in developed countries. Combined with an efficient system for law enforcement, these measures often, but not always, overcome the problems of screening, incentives and enforcement. The size of credit, and also the overall level of society, makes institutions like these inappropriate for the rural credit market of developing countries. Instead, in their place is reliance on market interlinkages, segmentation and social pressure.

\section{Informal Credit}

We define informal credit in Ghana to embrace all financial transactions that take place beyond the functional scope of banking and other financial sector regulations. In this respect of informal credit in Ghana, we first described briefly in this section some of the informal units operating there and then proceeded to analyze their structural and operational characteristics.

Informal credit transactions can be grouped into noncommercial transactions, such as transactions between relatives and friends or small-scale group arrangements, and commercially based ones, conducted by savings collectors, estate owners, landlords, traders, and moneylenders. Informal financial units have been formed to meet the demand of a diverse customer base (Nissanke and Aryeetey, 2006). There has been substantial increase in demand for informal credit and savings in Ghana. This is due to an increase in unsatisfied demand for formal sector credit, which has been continuously restrained as part of stabilization efforts.

Ghana has a mature informal credit system in the rural areas that satisfies the urgent demand of the people for production and consumption. The informal credit system also helps to meet the pressing social commitment, such as paying the cost of the sick and funeral expenses (Ekumah and Essel, 2001). Sources of the informal credit are relatives, friends, traders and/or private moneylenders and landlords. Relatives, that is, close family relations, and friends do not normally charge interest. But depending on their claims to the sources of the money being lent, some may do so. In any case, interest charged by relatives and friends are, however, exceptions to the rule. With regard to the landlord, Sarris and Shams (1991) argue that a loan can attract interest or have a transaction cost in the form of labor service to the landlord. The interest rates charged by moneylenders are between a 50-percent and 100-percent base on the period that was contracted with the borrower (Ekumah and Essel, 2001). One of the characteristics of informal credit in Ghana is that it does not attach different risk to borrowers within their usual clientele. Borrowers are preselected by membership requirement especially in group-based arrangements. Traders on the other hand only lend to people with whom they have a business relationship. According to Nissanke and Aryeetey (2006), moneylenders are the only informal lenders that do not lend to distinct clientele. A study by Udry $(1990,1994)$ posits that screening in the formal sector depends extensively on the personal knowledge of borrowers. He explains that the development of personal ties and proximity is a mechanism for countering the effects of adverse selection and moral hazard.

In Ghana, moneylenders do not require a business relationship with applicants for loan approval. Given the lack of competitive pressure, moneylenders respond to possible risk variations by charging different interest rates to different borrowers. Nissanke and Aryeetey (2006) explained that moneylenders and other informal groups do not monitor loans because of free information circulation in their operating circles. Udry (1994) stated that nonpayment of loans in the informal sector is relatively low. Nissanke and Aryeetey (2006) observed in their studies that 70 to 80 
percent of the sample used reported no delinquency in terms of borrowing. They also observed that the largest proportion of defaulters' borrowers was found in rural credit unions and cooperatives. They pointed that nonpayment of informal credit is generally attributed to borrowers' cash-flow problems, while many urban lenders think it is a mixture of cash-flow problems and low commitment on the part of borrowers to settle debts. While repayment trends in the semiformal and informal sectors are much better, it is seldom the result of more "aggressive" contractenforcement procedures. Nissanke and Aryeetey stressed that contract-enforcement mechanisms differ greatly based on lender-borrower relationships. Among group-based arrangements and in rural areas, mechanisms such as peer pressure or a potential use of social stigmatization are effective. Udry (1990) stated an instance where a lender's plea with community authorities in response to a perceived default led to a prompt repayment. Ironically, when the number of defaulters in a rural cooperative arrangement is large, the sanction of stigmatizing an individual fails to be effective.

\section{INFORMAL UNITS OPERATING IN GHANA}

\section{Group Lending}

This is a system of loans that has become increasingly popular among many lenders across the nation with the aim of improving the access of credit to the rural people. Padmanabhan (1989) in his book Rural Credit defines group credit as nonindividual credit in which credit is given to groups of farmers who are joined together to form an association such as a cooperative, credit union, user's society, etc., where such organizations play a role in securing, management, use, and repayment of such credit. Thus, the association acts as an intermediary between the creditgranting authority and the ultimate user. Padmanabhan noted that whether the groups are formed spontaneously, through that catalytic work of a trained animator, or a motivated bank worker in the field, or even through interaction with other groups, they must reflect the members own motivation and aspirations. The members must perceive the group as an instrument for furthering their own economic and social interests and enhancing their human dignity. Obtaining credit is only one phase in this process. Some major weakness of group lending has come to the surface of late. Group leaders have been found taking undue advantage of the facilities available to members. Groups consisting of extending family members have failed to meet repayment obligations. In Ghana, lenders could not enforce joint liability. When several members of the group failed to repay the loan, the lender has to absorb the loss. The group defaulters are then dismissed from the group and a new loan has to grant to reconstituted group. Among groups formed within extended families, it was found difficult to impose discipline on members who were relationships as well. In some cases, members who were prompt in their repayment found it burdensome to own the debts of defaulting fellow members, and consequently opted out of the group. One of the potential advantages of the group lending is the opportunity for reducing the administrative costs of a public credit agency which makes small loans to individual.

\section{Moneylenders}

Moneylenders have been known to be significant commercial lenders, often lending from surplus income earned from farming or trading. Moneylenders are made up of estate owners, traders, grain millers, small-holder farmers, employers, relations and friends, credit unions, and cooperatives (Aryeetey, 1994). Moneylenders will continue to remain a valued source of credit in rural areas for a longer period of time because of their easy approachability, informality, and flexibility. The business of these regular moneylenders is often based on the moneylender's intimate knowledge of his clientele, which has relatively few links with other financiers whether formal or informal. Credit from this source is expensive and, therefore, often serves as a last resort. Interest rates in this market often tend to be high, especially when estimated on an annual basis. The moneylender does incur costs in the form of information and transaction costs; the risk is associated with lending to individuals who are otherwise not creditworthy, and the maintenance of idle cash balances by the moneylender for immediate supply of credit. These factors may explain a substantial part of the high annualized interest rates that are sometimes observed in these markets. Long-standing clients who have established credit worthiness are charged a lower interest rate than those who are first entering the market. 


\section{Susu Collectors}

Susu collectors are informal finance providers who supply poor households with short-term and flexible financial products. These collectors have grown steadily over many years in Ghana. Between 1990 and 1992, Susu collectors in Ghana increased the size of their clientele substantially, and the growth in clientele was more rapid in urban areas than in rural areas. The monthly average of depositors in Accra per collector increased from 155 in 1990 to 221 in 1991 and 290 in 1992, a total increase of 48 percent over the period (Aryeetey, 1994). In 2003, Susu collectors amounted to 4,032 and they served between 100 and 250 customers in rural and urban areas, respectively (see Table 1).

Table 1: Characteristics of Susu Collectors in Ghana

\begin{tabular}{|l|c|c|c|}
\hline \multicolumn{1}{|c|}{ Region } & Number of Susu Collectors & $\begin{array}{c}\text { Average Number of } \\
\text { Customers per Susu } \\
\text { Collectors }\end{array}$ & $\begin{array}{c}\text { Total Number of } \\
\text { Customers of all Susu } \\
\text { Collectors }\end{array}$ \\
\hline Urban & 1,848 & 250 & 462,000 \\
\hline Semi-urban & 1,564 & 200 & 312,000 \\
\hline Rural & 620 & 100 & 62,000 \\
\hline
\end{tabular}

Source: Ghana Cooperative Susu Collector's Association, 2003: 4.

A participant commonly has to save with a Susu collector for several months in order to prove his trustworthiness, as well as his cash flow, before being allowed to borrow. Based on the style of operation, the Susu collector has to visit his or her client everyday to collect a fixed amount of money depending on the client's cash flow for a period of 31 days. The daily contributions of a customer are recorded in a savings account. The total amount of the contribution is paid in a lump sum while the Susu collector keeps one day's contribution as a fee for his services. Additional money is earned by the Susu collector from either reinvesting his client's contributions in short-term projects or from depositing the contributions at a commercial bank, and receiving interest from the savings account. The same style of operation and fees is earned when a Susu collector bequests a credit to a customer. In this respect an amount of money is drawn from the customer's daily contributions and is repaid through daily Susu contributions afterwards. Susu collectors are not subject to regulation and savings with Susu collectors can be more risky.

\section{Warehouse Receipt Credit (WRC)}

A further category of informal providers of credit are wholesalers, who grant credits in goods to market women. Even though no interest is charged explicitly, the goods have to be repaid at prices per unit that are about 15 percent above the purchase market price, which is a considerable fee. While credit in goods from wholesalers is the most important type of informal credit after a total loss, this credit relationship reinforces the polarization between market women and wholesalers. According to Coulter and Onumah (2002), warehouse receipts are documents written by warehouse operators as proof that specified commodities of stated amounts and quality have been stored at particular locations by named depositors. The depositor may be a producer, farmer, group trader, exporter, processor, or indeed any individual or corporation. The commodity remains the property of the depositor until sold at market, while the warehouse operator can extend credit in the form of cash to people who deposit commodities in his or her warehouse. In this respect lenders can mitigate credit risk by using the stored commodity as collateral. This form of collateral is more readily available to rural producers and may be easier to liquidate than the type of asset traditionally accepted by banks as collateral. The main limitation of this system is that it tends to exclude small holders and small-scale traders.

Some NGOs have tried to establish inventory credit systems for small-holder groups, for example the "Technoserve" system pioneered in Ghana. Although it benefited participating farmers, the system has not proved economically sustainable due to the small volumes of grain involved (Kwadjo, 2000). As observed by Coulter and Onumah (2002), there are several challenges to overcome when promoting a regulated WR system in Africa. These include a lack of supportive legal framework and opposition from business interests who are keen to preserve existing collateral management systems. 


\section{PROBLEMS FACING RURAL CREDIT}

Several credit programs face high costs in comparison with their disbursement rate, making it impossible for activities to be carried out on a commercial basis. It should be emphasized however, that many programs with a credit component include a range of activities, making it difficult to tell which costs are for credit activities and which are related to other activities (Jaramillo-Vallejo, 1994). High costs are due to the small size of most rural people's accounts in relation to the cost of service delivery. A low level of economic activity, low rural population density, and poor infrastructure will also increase operating costs. Specialized agricultural lenders for example have a number of operational problems, which include institutional viability and efficiencies in credit delivery. A review of these problems shows the negative consequences of supply-leading finance and also provides some guidance as to the kinds of reforms necessary for improved financial market performance (Bourne and Graham, 1984).

Another defect in the operations of specialized agricultural lenders is the high cost of supervising loans. This includes emphasis on close and continuous monitoring of loan use. Credit officers make frequent visits for the alleged purpose of encouraging farmers to adopt new practices and follow farm plans. The credit institution accepts the responsibility for providing technical assistance and hires staff accordingly. All these activities add to administrative costs. Loan monitoring for purposes of preventing credit diversion and ensuring loan repayment is often ineffective, and credit supervision ends up being wasteful. Different arrangements to lower costs have been tried by formal lenders. For instance, collateral is often demanded (Hoff and Stiglitz, 1990). This procedure can be very costly for the borrower however, who is required to produce the necessary documents. It also excludes a large proportion of the rural poor, as formal lenders then have to specialize in areas where clear land titles make collateral possible. When financial institutions impose high transaction costs, small depositors become discouraged. A study in Nigeria by Padmanabhan (1989) found that simple transactions at commercial banks in Lagos took 8 or 10 times longer than in the U.S. or UK, due to faulty procedures and inadequate training of bank staff.

While informal lenders are often perceived to have "outrageously" high rates, in contrast with formal lenders, there appears to be considerable variation in the rates of different informal lenders in many countries. Available evidence suggests that interest rates have been substantially higher than those prevailing in the formal market. Aryeetey (1994) observed from an analysis of variance in the monthly rates of Ghanaian informal lenders that the main source of variation was the type of lender. Also, an analysis of the mean monthly interest rates by type of lender indicated that all other mean interest rates differed significantly from those of moneylenders (see Table 2).

Table 2: Mean Monthly Interest Rates of Informal Lenders in Ghana (\%), 1992

\begin{tabular}{|c|c|c|c|c|c|c|c|c|}
\hline Region & Moneylender & & $\begin{array}{c}\text { Susu } \\
\text { Collector }\end{array}$ & & SCC/SCA & & $\begin{array}{l}\text { Credit } \\
\text { Union }\end{array}$ & \\
\hline & Urban & Rural & Urban & Rural & Urban & Rural & Urban & Rural \\
\hline $\begin{array}{l}\text { Greater } \\
\text { Accra }\end{array}$ & 8 & 7 & 3.3 & 3.3 & 5 & 5 & 6 & 5 \\
\hline Eastern & 10 & 10 & 3.3 & 3.3 & 5 & 5 & 10 & 10 \\
\hline Volta & 10 & 8 & 3.3 & 3.3 & 5 & 3 & 5 & 5 \\
\hline Central & 10 & 7 & 3.3 & 3.3 & 5 & 3 & 3 & 3 \\
\hline Ashanti & 9 & 9 & 3.3 & 3.3 & 3 & 3 & 3 & 5 \\
\hline $\begin{array}{l}\text { Brong } \\
\text { Ahafo }\end{array}$ & 10 & 7 & 3.3 & 3.3 & 5 & 10 & 10 & 5 \\
\hline $\begin{array}{l}\text { Upper } \\
\text { West }\end{array}$ & - & - & 3.3 & 3.3 & 5 & 10 & 3 & 3 \\
\hline
\end{tabular}

Source: Aryeetey, E., Financial Integration and Development in Sub-Saharan Africa (1994).

According to Aryeetey (1994), if informal lenders attached different risks to different borrower categories, a possible way of doing this would be to apply different interest rates. He found that not to be the case in many instances. Aryeetey observed that interest rates charged by moneylenders did really vary from one lender to another. He concluded that interest rates in rural areas are not much different from the urban interest rates. 
There has been a considerable debate on the degree of monopoly in the informal markets, prompted by the observation of high rates of interest. A recent survey of a local market in Pakistan found an excess supply of lenders, indicating that, at least in that market, there is likely to be a fair degree of competition among moneylenders. This suggests that entry into the business of lending may be quite free. Aleem (1990) found that the main reason for the high interest rate were (a) the high costs of loanable funds which themselves were sometimes obtained from the informal markets, (b) the relatively large costs of monitoring and administering the loan, and (c) the costs associated with delinquency. Since the size of the informal markets can be expected to shrink as deregulation takes place and as financial innovation is permitted in the formal sector, one would expect interest rates in the informal markets to show a declining trend over time. This would happen not only because of a trend toward liberalization in the financial market but also because of improved information flows and means of reducing transaction and monitoring costs. As interest rates in the informal markets decline, the spread between the interest rates in the formal sector and the informal sector also declines.

Lack of Innovations: One of the main reasons is that governments, financial intermediaries, and donors have concentrated on supply-side interventions when undertaking reforms and innovations. They have paid insufficient attention to improving access to rural finance through reducing risks in the financial environment. Innovative financial institutions including banks and cooperatives have shown that it is possible to provide viable financial services to small-scale agriculture in rural areas. They have done this by adopting financial products, making creative use of delivery mechanisms to reduce costs and adopting new technologies. Further innovation is needed to extend the benefits of financial services to wider rural areas.

Experience also indicates that providing credit to farmers in developing countries has not always led to the rapid adoption of new technology and methods. Even under the World Bank system of lending to large farms, the overall production increases have been more the result of expansion at existing levels of skills than the use of new technology. Risks, profitability, and the expediency of technology often have appeared more important than credit per se. But when technology meets with approval, then credit is the major factor in its utilization. Generally speaking, no more than 10 to 15 percent of the farmers in low-income countries find formal agricultural credit available to them. In the case of small farmers, the percentage is even lower.

Marketing in many areas of the world, including several African countries, is one of the most difficult problems facing the small-farm operator. Marketing systems are often incapable of handling any large increase in farm production resulting from a successful credit program. The power of the marketing system is often seen as eroding the higher profits that farmers should receive. The system generally forces farmers to sell when prices are low because farmers lack access to storage facilities where produce may be held until the prices rise.

In many low-income countries like Ghana, specialized agricultural lenders have been formed in the past several decades to achieve rural development objectives: rapid increases in agricultural production, expansion in rural employment and income, modernization of agricultural technology and practices, domestic self-sufficiency in food production, a favorable agricultural balance of trade, and equity within the rural sector and between rural and urban areas. The results of these programs are not encouraging (Von Pischke, 2003). Because of the fungibility, divisibility, and substitutability of money, it is difficult to attribute specific increases in production and income to credit activities. Also, in some cases, credit expansion has coincided with output decreases and more agricultural imports. Rural inequality appears to have increased as a consequence of agricultural credit policy. Furthermore, many rural credit institutions and programs are not financially viable. Some of the portfolios tended to decline or stagnate rather than grow in real or nominal terms.

The history of high delinquency rates in the credit programs suggests that either the system is being exploited by the borrowers or the farmers are, in fact, not creditworthy. The World Bank considers reducing the high rate of delinquency and default as the most important issue facing government credit programs attempting to operate on a self-sustaining basis. If a high proportion of an institution's loans are not rapid, the lender's capital is soon depleted and the institution must cease to function as a loan agency unless government provides additional funds. Miller (1977) reported that on a maize group farming scheme in Ghana, $\$ 869,767$ had been loaned during the three years 1969-1971, but that only $\$ 584,297$ had been collected by June 30, 1972, for a repayment rate of 67 percent. In Nigeria, the repayment performance was similarly poor for rice-maize group loans made in 1972. Loans to 30 rice 
groups involving 390 farmers had been 75 percent repaid by June 30, 1973, but the repayment rate varied widely from 32.9 percent for rice loans in one administrative area to 90.7 percent in another. The high rate of delinquency is associated with enforcement problems which are common in the Ghanaian society. In this sphere, if borrowers even have assets that can be used as collateral, they are often not acceptable to banks because of the high cost and long delays in using judicial enforcement mechanisms. In some cases, rural population lacks adequate collateral that can be use as a hedge against loans or credit. This has blocked rural population access to rural credit and is related to poorly defined property and land-use rights and weak land and property markets (World Bank, 2001).

High, and often covariant, risk in the rural economy is related to the dominance of agriculture, which accounts for a high percentage of Gross Domestic Product (GDP). The long gestation period for many agricultural investments and the seasonality of output usually leads to uneven cash flow and variable demand for savings and credit. Commercial lenders consider agricultural credit too risky due to higher administration costs, the lack of viable collateral, regional limitations, the present nature of small-unit farming, and the land tenure system. The liquidity in the credit system has largely eliminated incentives for banks to motivate credit through rural savings. It is often noted that commercial banks in Ghana do not reach and service many farmers, presumably because producers are not credit-worthy or the information needed by banks to determine their credit-worthiness is too expensive to collect and interpret. This leads some to argue that specialized institutions or programs (usually with a costly overhead of supervisory credit personnel) are required to reach these potential customers, even if the costs far exceed interest receipts.

\section{CONCLUSION}

This paper identified the problems that have hindered the effectiveness of the rural credit market in Ghana and was based on the theoretical understanding of the rural credit market. The study has also identified high cost, interest rate, lack of collateral, inadequate innovation, and high delinquency rate as the main factors that have hindered the effectiveness of the rural market in Ghana. Group lenders, moneylenders, Susu collectors, and warehouse receipt credit were also identified as the main informal operating activities in Ghana. The paper has provided some valuable information on the rural market in Ghana, especially the influencing factors that have undermined the rural market development. Another critical finding is that the lack of collateral significantly increases the probability of borrowing from the informal market as well as the interest rate charged on informal loans. This is probably the area with greater scope for potentially effective government action. Based upon the experience gained from this study, policymakers are advised to place more emphasis on encouraging rural financial markets to mobilize savings and revise interest-rate policy.

\section{RECOMMENDATIONS}

Despite the confusion that surrounds rural financial markets, the treatments for its problems are relatively simple. First and foremost much more emphasis must be placed on encouraging rural financial markets to mobilize savings. It will also be necessary to revise interest-rate policy. High rates on loans would reduce the demand among those who use large amounts of cheap credit, allow more lenders to cover their costs, and encourage lenders to reduce the costs of transacting loans for both borrowers and themselves. Policymakers should not try to accomplish too much with credit projects. Product prices, crop yields, and the costs of production are much more powerful determinants of farmers' decisions than is credit availability or interest rates.

The concern of the government in developing countries that we assume to be rational is to provide cheap and adequate credit to small and poor farmers since credit is viewed as a production input, and accessible and affordable inputs are essential to increasing production and incomes. Therefore, if the government perceives the rural credit market to be characterized by lack of funds and the presence of monopolist moneylenders leading to sky-high interest rates, a rational response would be to inject credit into the market, increasing the supply of funds, thereby hoping to drive down interest rates. The key role for government should be to create the externality-like effects by reducing the costs of enforcement and information. This can be done, for example, by enforcing property rights (land titling) and undertaking investment in rural infrastructure to make agriculture less risky, thereby reducing asymmetric information between lenders and borrowers. 
Gonzalez-Vega (2003) argues that the state can make the enforcement of prudential regulations more robust to support financial sector development, thus, creating trust in financial intermediaries and encouraging savings. He adds that policies to promote competition and lower-entry barriers to the rural financial markets will reduce fragmentation of the sector and contribute to its development. Innovations in financial products will help improve the health and performance of the financial sector. According to Wenner and Arias (2003), in Latin America and the Caribbean, financial debt rose for 20 out of 25 Inter-American Development Bank (IADB) borrowing member countries during 1990-1997, due to the implementation of the financial systems approach.

Rural households are highly vulnerable to the income shocks that occur when unreliable weather causes large differences in yields from year to year. Seeks (2003) and Von Pischke (2003) argued that insuring against risk can make better rural financial markets and lessen the difficulties of giving loans to customers. However, the choices to alleviate agricultural risks are very few in most developing countries, particularly for small holders in rural communities (Cohen and Sebstad, 2003). Farmers in some developed nations can use crop insurance to alleviate crop-yield risk. In this case, claims can be made if the yield falls short of a predetermined average (Bryla, 2003). However, traditional insurance is not feasible in most rural communities because the high cost of intensive monitoring to avoid the moral hazard problem implies high premiums (to ensure sustainability) and most farmers cannot afford them. Only high-risk farmers, who may need insurance to access credit, will have sufficient incentives to buy insurance, implying that adverse selection becomes a major problem (Skees 2003) The insurance is seen by banks as liquid collateral, which enables farmers to repay loans even in the event of a yield catastrophe (Bryla, 2003).

Warehousing schemes must appeal to a wide clientele, not just small holders, and build large volumes, reduce unit costs, and improve overall system efficiency.

\section{AUTHOR INFORMATION}

George Owusu-Antwi is a DBA student at Huizenga School of Business and Entrepreneurship, Nova Southeastern University, and consultant at P. G. Consulting and Tax Service in Columbus, Ohio. The author has had many years' experience in banking and taxation and holds three masters' degrees in the field of finance, economics, and education. In 1992, he obtained a Professional Banking Diploma certification from the American Institute of Banking in Bethesda, Maryland. The author's research interest includes financial institutions and markets, corporate finance, international finance, and macroeconomics.

James Antwi is currently a lecturer at the Ghana Institute of Management and Public Administration (GIMPA) in Ghana, and has over 12 years experience in information technology, project management, and finance. He is a PMP certify and holds three masters' degrees in the field of system science, business administration, and financial economics. The research interest of this author includes information systems, financial economics, and project management.

\section{REFERENCES}

1. Aleem, I. (1990). Imperfect information, screening, and the costs of informal lending: A study of a rural credit market in Pakistan. World Bank Economic Review (4) 3, 329-349.

2. Aryeetey, E. (1994). Financial integration and development in sub-Saharan Africa: A study of informal finance in Ghana. Overseas Development Institute Working Paper 78, London: ODI.

3. Bali Swain, R. (2001). Demand, segmentation and rationing in the rural credit markets of Puri. Dissertation. Department of Economics, Uppsala University.

4. Besley, T. (1994). How do market failures justify interventions in rural finance markets? World Bank Research Observer (9), 27-47.

5. Bourne, C., and Graham, D. H. (1984). In undermining rural development with cheap credit problem with specialized agricultural lenders. 43-45. 
6. Bryla, E. (2003). The use of price and weather risk management instruments. Paper Presented at Broadening Access and Strengthening Input Market Systems-Collaborative Research Support Programme (BASIS-CRESP). Conference on paving the way forward for rural finance, 2-4. Washington, DC.

7. Cohen, M., and Sebstad, J. (2003). Reducing vulnerability: The demand for microfinance. A Synthesis Report. Nairobi: Micro Save Africa.

8. Coulter, J., and Onumah, G.E. (2002). The role of warehouse receipt systems in enhanced commodity marketing and rural livelihoods in Africa. Food Policy (27), 319-337.

9. Ekumah, E. K., and Essel, T.T. (2001). Gender access to credit under Ghana's financial sector reform: A case study of two rural banks in the central region of Ghana. IFLIP Research Paper. 01-4.

10. Ghana Cooperative Susu Collector's Association (2003). GCSCA Strategy 2004-2006. GCSCA, Accra.

11. Gonzalez-Vega, C. (2003). Lessons for rural finance from microfinance revolution. In Wenner Mark, Javier Alvarado, and Francisco Galarza (eds.), Promising Practices in Rural Finance: Experiences from Latin America and the Caribbean. Washington, DC: Inter-American Development Bank.

12. Hoff, K., and Stiglitz, J. E. (1996). Imperfect information and rural credit markets: Puzzles and policy perspectives. The Economics of Rural Organizations: Theory, Practice and Policy. Ed. Karla Hoff, Avishay Braverman and Joseph Stiglitz Oxford University Press. 33-52.

13. Hoff, K. and Stiglitz, J. (1990). Imperfect information and rural credit markets: Puzzles and policy perspectives. World Bank Economic Review (4) 3. 235-250.

14. ISSER, (1994). State of the Ghanaian economy in Ghana: Institute of Statistical, Social and Economic Research (ISSER) of the University of Ghana.

15. Jaramillo-Vallejo, J. (1994). Comment on the role of the state in financial markets, by Stiglitz. Proceedings of the World Bank annual conference on development economics 1993, supplement to The World Bank Economic Review and The World Bank Observer.

16. Kwadjo, G. T. M. (2000). Inventory credit: A financial product in Ghana. Paper Presented at Conference on Advancing MicroFinance in Rural West Africa. Bamako, Mali.

17. Long, M. (1994). Comment on directed credit programs for agriculture and industry, by Calomiris and Himmelberg. Proceedings of the World Bank annual conference on Development Economic Review and the World Bank Research Observer.

18. Milgrom, P. and Roberts, J. (1992). Economics, Organization and Management. Englewood Cliffs, NJ: Prentice-Hall.

19. Miller, L. F. (1997). Agricultural credit and finance in Africa. Published by the Rockefeller Foundation.

20. Nissanke, M., \& Aryeetey, E. (2006). Institutional analysis of financial market fragmentation in subSaharan Africa. A risk-cost configuration approach Research Paper No. 2006/87. United Nations.

21. Padmanabhan, K. P. (1989). Rural credit. New York: St. Martin's Press.

22. Sarris, A., and Shams, H. (1991). Ghana Under Structural adjustment: The impact on agriculture and the rural poor. New York: New York University Press.

23. Seeks, J. R. (2003). Risk management challenges in rural financial markets: Blending risk management innovations with rural finance. Paper Presented at Broadening Access and Strengthening Input Market Systems-Collaborative Research Support Programme (BASIS-CRSP). Conference on paving the way forward for rural finance, 2-4. Washington, DC.

24. Stiglitz, J. (1994). The role of the state in financial markets. Proceedings of the World Bank annual conference on development economics 1993, supplement to The World Bank Economic Review and The World Bank Research Observer.

25. Stiglitz, J. E., and Weiss, A. (1981). Credit rationing in markets with imperfect information. The American Economic Review (71) 3, 393-410.

26. Urdry, C. (1990). Credit markets in Northern Nigeria: Credit as insurance in a rural economy The World Bank Economic Review, (4) 3.

27. Udry, C. (1994). Risk and insurance in a rural credit market: An empirical investigation in Northern Nigeria. Review of Economic Studies 6 (13), No. 208, 495-526.

28. Varian, H. (1990). Intermediate Microeconomics. A Modern Approach (2nd ed). New York: W. W. Norton.

29. Von Pischke, J. D. (2003). The evolution of institutional issues in rural finance: Outreach, risk and sustainability. Paper Presented at Broadening Access and Strengthening Input Market SystemsCollaborative Research Support Programme (BASIS_CRSP). Conference on paving the way forward for rural finance, Washington, DC. 
30. Wenner, M., and Arias, D. (2003). Agricultural Insurance in Latin America: Where are we? Paper Presented at Broadening Access and Strengthening Input Market Systems - Collaborative Research Support programme (BASIS-CRSP). Conference on paving the way forward for rural finance, Washington DC.

31. World Bank, (2001). Financial systems and development. World Development Report. New York: Oxford University Press.

32. World Bank. (2004). Investments in rural finance for agriculture. Agriculture Investment Sourcesbook, chapter 7, by D. Pearce, A. Goodland, and A. Mulder. Washington, DC: World Bank.

33. Yaron, J., Benjamin, M. and Piprek, G. (1997). Rural finance: Issues, design and best practices.

Environmentally and Socially Sustainable Development (ESSD). Studies and Monographs Series 14,. Washington, DC: World Bank. 